\title{
PENGEMBANGAN MEDIA PERDASAWA (PERMAINAN DAKON AKSARA JAWA) MATA PELAJARAN BAHASA JAWA PADA KELAS V SEKOLAH DASAR
}

\author{
Yeni Dwi Wulandari, Endang Poerwanti, Nafi Isbadrianingtyas \\ SDN 2 Dongko dan SDN 3 Ngerdani \\ e-mail :yeni29wulan@gmail.com
}

\begin{abstract}
This study aims to produce a media product PERDASAWA has a level of validity as criteria media to help students read Javanese alphabet in $5^{\text {th }}$ Grade of elementary school. This study uses research R \& D (Research and Development) and the type of research is the development of research. The results of this study indicate that the use of the media can help students in learning to read Javanese alphabet. This is evidenced by the results of validation to some experts, among others, media expert validation by $92.3 \%$, materials expert validation $83.6 \%$, and validation of the Javanese learning experts Elementary School $81.8 \%$. While a small group of trial results showed that $80 \%$ of learning the Javanese using the hare media received a positive response from students and fit for use for learning. The trial results showed that a large group of $92.4 \%$ of learning the Javanese using the media received a positive response from students and a very decent and effectively used as a medium of learning. Media PERDASAWA need of improvement in terms of font size and line spacing correct Java script writing.
\end{abstract}

Keywords : Development, PERDASAWA, Reading, Java Script

\begin{abstract}
Abstrak: Penelitian ini bertujuan menghasilkan produk media PERDASAWA yang memiliki tingkat kevalidan sebagai kriteria media untuk membantu siswa membaca aksara Jawa pada siswa kelas V SD. Penelitian ini menggunakan penelitian R\&D (Research and Development) dan jenis penelitian yang dilakukan adalah penelitian pengembangan. Hasil penelitian ini menunjukkan bahwa penggunaan media dapat membantu siswa dalam belajar membaca aksara Jawa. Hal ini dibuktikan oleh hasil validasi beberapa ahli antara lain, validasi ahli media sebesar $100 \%$, validasi ahli materi sebesar 95.71\%, dan validasi ahli pembelajaran bahasa Jawa Sekolah Dasar sebesar 93.07\%. Sementara hasil uji coba kelompok kecil menunjukkan bahwa $88.75 \%$ pembelajaran bahasa Jawa menggunakan media KANCIL mendapat respon positif dari siswa dan layak digunakan untuk pembelajaran. Hasil uji coba kelompok besar menunjukkan bahwa $94.37 \%$ pembelajaran bahasa Jawa menggunakan media mendapat respon positif dari siswa dan sangat layak dan efektif digunakan sebagai media pembelajaran. Media KANCIL ini perlu perbaikan dalam segi ukuran font dan spasi penulisan aksara Jawa yang benar.
\end{abstract}

Kata Kunci : Pengembangan, Media PERDASAWA, Membaca, Aksara Jawa

\section{PENDAHULUAN}

Pembelajaran bahasa Jawa sangatlah penting dan memiliki makna yang luar biasa. Dalam pembelajaran bahasa Jawa mengandung pendidikan untuk budi pekerti. Sehingga pembelajaran bahasa Jawa penting dan wajib diajarkan pada siswa Sekolah
Dasar sebagai dasar penanaman budi pekerti yang luhur. Pembelajaran bahasa Jawa merupakan pebelajaran yang berdiri sendiri dan tidak terintegrasi dengan mata pelajaran yang lain, sehingga pembelajaran ini khusus diberikan kepada siswa secara terpisah dan diajarkan dalam muatan lokal (Prihatin, 2015:16) 
Agar siswa terampil dalam pembelajaran bahasa jawa, maka ada empat aspek yang harus dikuasai, yaitu keterampilan mendengarkan, berbicara, membaca dan menulis. Dalam keterampilan membaca dan menulis terdapat satu kompetensi tentang Pembelajaran Aksara atau Huruf Jawa. Materi aksara Jawa pada siswa kelas V yaitu terdapat materi aksara Jawa menggunakan pasangan. Dua hal yang perlu diperhatikan dalam menyampaikan materi aksara Jawa yaitu bentuk hurufnya dan cara bacanya. Sedangkan siswa dituntut mampu membaca Aksara Jawa. Namun pada kenyataannya kesulitan membaca Aksara Jawa menggunakan pasangan masih banyak dialami oleh siswa. Sehingga guru perlu memperhatikan cara-cara mengajar dengan menggunakan media yang edukatif.

Berdasarkan hasil wawancara dan observasi tanggal 23 oktober 2017 di SDN 2 Dongko Kec. Dongko Kab Trenggalek tahun ajaran 2017-2018 dengan guru kelas $\mathrm{V}$ bahwa siswa masih mengalami kesulitan dalam membaca materi Aksara Jawa menggunakan pasangan. Dari 10 siswa yang ada dalam kelas tersebut, hanya 4 orang siswa yang bisa membaca Aksara Jawa, sedangkan 6 siswa lainnya masih bingung dan belum hafal membaca Aksara Jawa dengan pasangan. Dari 6 siswa yang belum bisa membaca Aksara Jawa, 1 siswa bernama Ratih membaca Aksara Jawa dengan cara sebagai berikut :

"ha,na,ca,ra,ka,sa,ta,da,wa,la.pa,dha,ja,ya, nga,ma,ga,ba,tha,nga".

Kesulitan membaca Aksara Jawa tersebut disebabkan oleh beberapa faktor dari siswa antara lain: (1) minat siswa membaca aksara jawa yang kurang, terbukti hanya 4 siswa yang bisa membaca (2) siswa belum hafal membaca aksara jawa, terbukti siswa masih sulit membedakan huruf da dan sa serta pasangan ha ( $\mathrm{Nl}$ ) dan la

( $(\pi \sim$ ), (3) sumber belajar siswa yang minım terbatas pada pepak bahasa jawa.

Sedangkan faktor dari guru dalam pembelajaran yaitu: (1) guru dalam mengajar hanya menggunakan metode konvensional (ceramah dan tanya jawab), (2) selain dalam proses pembelajaran yang kurang menarik siswa, kurangnya media yang mendukung proses pembelajaran juga sangat berpengaruh, Hal tersebut sesuai dengan kutipan wawancara yang dilakukan peneliti, dimana guru sebagai berikut :

"Saya Jarang menggunakan media, biasanya saya tuliskan dipapan kemudian siswa saya suruh menyalin dibuku masing-masing dan diakhir pembelajaran saya beri soal latihan".

(3) guru mengajar menggunakan sumber belajar buku pepak bahasa jawa dan buku Tantri Basa Jawa. Sedangkan faktor sarana dan prasarana dikelas yaitu (1) kelas tidak memiliki media pembelajaran 2D (gambar aksara jawa ) atau 3D, (2) papan tulis masih menggunakan papan dan kapur (blackboard), (3) tidak terdapat LCD dan proyektor..

Berdasarkan hasil wawancara dan observasi tanggal 28 oktober 2017 di SDN 3 Ngerdani Kec. Dongko Kab Trenggalek tahun ajaran 2017-2018 dengan guru kelas $\mathrm{V}$ bahwa siswa masih mengalami kesulitan dalam membaca materi Aksara Jawa menggunakan Pasangan. Guru dalam melaksanakan proses pembelajaran menggunakan metode hafalan. Siswa diminta untuk menghafalkan, salah satu siswa menghafal Aksara Jawa sebagaiberikut :

"ha, na, ca, ra, ka, da, ta, sa, wa, la, pa, dha, ja, ya, nya, ma, ga, ba, tha, nga"

"Ngo to bo go mo

Nyo yo jo do po

Lo wo so to do Ko ro co no ho" 
Selain itu beberapa faktor yang mempengaruhi kesulitan membaca aksara Jawa. Beberapa faktor dari siswa antara lain: (1) minat membaca aksara Jawa yang kurang, (2) belum hafal aksara Jawa, (3) Sumber belajar siswa yang minim terbatas pada pepak bahasa jawa dan gambar aksara jawa didinding. Sedangkan faktor dari guru yaitu: (1) guru mengajar hanya menggunakan metode konvensional (ceramah dan tanya jawab) dan hafalan, (2) kurangnya media yang mendukung proses pembelajaran, (3) guru mengajar menggunakan sumber belajar buku pepak bahasa jawa, buku tantri basa jawa dan buku paket. Sedangkan faktor sarana dan prasarana dikelas yaitu (1) kelas hanya memiliki media pembelajaran 2D seperti gambar aksara jawa, (2) papan tulis masih menggunakan whiteboard, (3) terdapat LCD dan proyektor.

Berdasarkan kondisi tersebut, sesuai dengan karakter siswa kelas V dengan umur 7-11 mereka berada pada tahap operasional konkrit dengan ciri senang bermain beregu, memiliki rasa ingin tau yang besar, mampu berfikir sistematis, senang bermain kelompok dan bergerak, maka hal yang perlu dilakukan agar pembelajaran membaca Aksara Jawa menggunakan pasangan mudah dipahami oleh siswa yaitu dengan membutuhkan media ketika belajar. Menurut (Sanjaya, 2008:207) media pembelajaran berfungsi sebagai alat bantu dalam pembelajaran, menarik dan memotivasi siswa untuk belajar. Sehingga materi yang dianggap sulit akan dapat disampaikan dengan mudah dan membekas diingatan siswa (Mulyana, 2008:257). Cara lain agar siswa senang dalam belajar yaitu dengan memasukan permainan dalam proses pembelajaran. Jadi siswa dapat bermain sambil belajar. Karena siswa
SD memiliki karakteristik senang bermain (Hariyanto (2008:61).

Pengembangan media permainan menjadi media pembelajaran menjadi salah satu alternatif bagi siswa agar tertarik dalam belajar. Permainan dakon salah satu media yang dapat dimodifikasi menjadi media pembelajaran. Permainan tersebut dapat meningkatkan kemampuan siswa dalam berfikir dan meningkatkan hasil belajar siswa (Pranowo, 2013:3). Permainan dakon yang peneliti akan lakukan ini memiliki beberapa keunggulan yaitu dapat dibawa kemana-mana, dapat dimaiankan oleh 4 orang atau lebih (secara kelompok), dapat dimainkan diruang terbuka, mengembangkan aspek kognitif, afektif dan keterampilan siswa. Perbedaan dakon ini dengan permainan dakon lainnya adalah bentuk dakon ini lingkaran dan dapat dilipat menjadi dua bagian, dengan desain kecik dari aklarik yang didalamnya memuat Aksara Jawa dan Pasangan, terdapat hiasana ukiran pada bagian luar dan dalam media, memiliki icon kartun wayang yang berada ditengah media, memiliki pion penjaga sebagai pembeda kelompok serta adanya penyisipan pertanyaan yang berada pada kartu soal.

Berdasarkan keunggulan dan cara penggunaan media tersebut, maka pengunaan media PERDASAWA ini diharapkan dapat meningkatkan proses pembelajaran khususnya materi membaca aksara jawa menggunakan pasangan. Sehingga siswa tidak kesulitan lagi dalam mempelajari materi aksara jawa, khususnya yang menggunakan pasangan.

Berdasarkan penjelasan diatas mak penelitian dengan judul " Pengembangan Media PERDASAWA (Permainan Dakon Aksara Jawa) Mata Pelajaran Bahasa Jawa Pada Kelas V SD" perlu segera dilakukan. 
Tujuan dai penelitian ini yaitu 1) Mengembangkan media PERDASAWA (permainan dakon aksara jawa) pada pembelajaran bahasa jawa kelas V SD, 2) Mengetahui kelayakan produk media PERDASAWA (permainan dakon aksara jawa) berdasarkan validasi ahli materi, media dan pembelajaran, 3) Mengetahui tingkat keterterapan media PERDASAWA (permainan dakon aksara jawa) pada pembelajaran bahasa jawa kelas V SD.

\section{KAJIAN PUSTAKA}

\section{Pembelajaran Bahasa Jawa di SD}

Pembelajaran adalah suatu proses interaksi antara guru dengan siswa dan sumber belajar dalam suatu lingkungan belajar (Sisdiknas, 2006:14). Menurut Mulyana (2008: 35) Bahasa Jawa merupakan bahasa daerah yang memiliki kedudukan sebagai identitas bangsa dan kebangaan dari daerah. Sehingga pembelajaran bahasa Jawa wajib diajarkan di sekolah dasar karena syarat dengan nilai-nilai yang baik. Mata pelajaran bahasa jawa di Sekolah Dasar tidak teritegrasi dengan mata pelajaran lainnya, sehingga dimasukan ke dalam muatan lokal (Mulok).

\section{Media Pembelajaran}

Kata media berasal dari kata medium yang berarti perantara atau pengantar. Makna umumnya yaitu sesuatu yang dapat mengantarkan informasi dari sumber informasi ke penerima iniformasi (Falahudin, 2014:6). Menurut Asyhar (2012:8) media dapat menyampaikan informasi secara efektif jika dilakukan dengan matang dan terencana. Sedangkan menurut Sadiman (2010:6) media pembelajaran dijadikan sebagai perantara pengantar pesan. Hal ini berarti media sebagai alat bantu yang digunakan guru untuk menyampaikan materi kepada siswa agar siswa mudah memahami apa yang dijelaskan (Meylinda, 2015:68).

Berdasarkan beberapa pengertian diatas dapat disimpulkan bahwa Media pembelajaran merupakan suatu perantara yang memudahkan guru dalam dalam menyampaikan materi kepada siswa, sehingga pembelajaran dapat terlaksana sesuai tujuan pembelajaran.

\section{Karakteristik Siswa Kelas V Sekolah Dasar}

Pada masa usia 7-11 tahun anak Sekolah Dasar berada pada jenjang kelas V. Mereka sudah memiliki ruang lingkup pergaulan yang lebih luas. Menurut Maisaroh (2011 :6). Dalam psikologi pendidikan dikenal dengan teori perkembangan anak. Teori ini dikembangkan oleh jean piaget dengan empat tahapan perkembangan yaitu sensorimotor stage (0-2 tahun), preoperational stage (2-7 tahun), concrete operational stage (7-11 tahun) dan formal stage (11- keatas). Apabila siswa berada kelas V Sekolah Dasar berarti mereka berada pada masa atau tahap concrete operational stage. Media perdasawa ini dikembangkan sesuai karakter siswa kelas $\mathrm{V}$ yang berada pada tahap tersebut.

\section{Permainan Dakon}

Dakon merupakan permainan tradisional yang sudah ada sejak lama. Dakon berbentuk bidang panjang dengan cekungan didalamnya. Didalam permainan dakon memili dua lumbung yang dijadikan sebagai tempat menaruh hasil yang diperoleh melalui permainan dakon. Cekungan dan lumbung pada dakon biasanya disi dengan biji-bijian, kerikil atau kulit kerang (Aisyah, 2011:10). Permainan ini memiliki jumlah lubang 16 dan memilik 2 lumbung. Skor kemenangan dalam permainan ini diperoleh dari hasil akhir 
pendapatan kecik yang berada dalam lumbung (Mandala, 2013). Piranti permainan dakon ini berupa papan kayu atau plastik berbentuk persegi panjang denan jumlah lubang sebanyak 7 x 2 yang melambangkan 7 hari dalam seminggu dan dilengkapi dengan kecik.

\section{METODE}

Model yang dikembangkan dalam penelitian ini mengacu pada model ASSURE. Model ASSURE telah dicetuskan oleh Heinich dan kembangkan oleh Smaldino, dalam buku "Instructional Technology \& Media For Learning. Model ASSURE ini dapat membantu guru dalam menjalankan proses pembelajaran didalam kelas dengan memadukan penggunaan teknologi dan media didalam kelas. (Smaldino, et al, 2011:112). Selanjutnya dikatakan bahwa : "The ASSURE model, on the other hand, is meant for the individual instructor to use when planing classroom use of media and technology" (Smaldino, et al, 2011: 55). Model ini dilain pihak membantu guru dalam proses pembelajaran didalam kelas.

Model pengembangan ASSURE yang terdiri atas analisis karakteristik siswa (analyze learner characteristics), menetapkan tujuan (state objectives), memilih, memodifikasi atau merancang dan mengembangkan media (select, modify or design media), menggunakan media (utilize media), Meminta tanggapan dari siswa (requires learner respons), evaluasi (evaluate). Berikut ini adalah gambar bagan prosedur pengembangan media pembelajaran menggunakan model ASSURE.

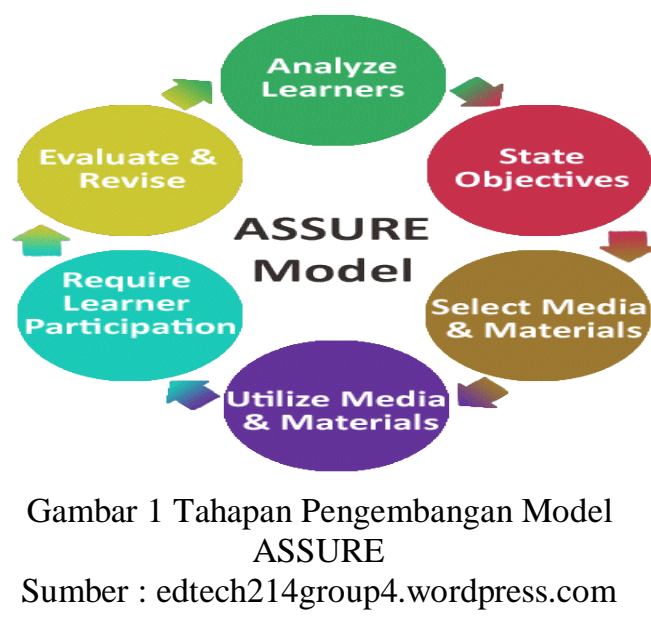

HASIL DAN PEMBAHASAN

Hasil penelitian

Hasil penelitian tentang pengembangan media PERDASAWA pada materi membaca kalimat aksara jawa menggunakan pasangan pada siswa kelas 5 Sekolah Dasar telah dilakukan peneliti di SDN 2 Dongko dan SDN 3 Ngerdani. Berikut ini penjelasan dari hasil penelitian yang telah dilakukan.

\section{Pengembangan Media \\ PERDASAWA dengan model ASSURE}

a. Analyze Learner Characteristics (analisis karakter siswa)

Analyze Learner Characteristics bertujuan untuk menganalisis karakteristik siswa di sekolah. Media dikatakan efektif bila ada kesesuaian antara karakteristik siswa dengan media yang digunakan. Data analisis ini berdasarkan hasil Observasi awal yang dilakukan pada tanggal 23 oktober 2017 di SDN 2 Dongko Kec. Dongko Kab Trenggalek tahun ajaran 2017-2018 dan tanggal 28 oktober 2017 di SDN 3 Ngerdani Kec. Dongko Kab Trenggalek tahun ajaran 2017-2018. Berdasarkan pembelajaran bahasa jawa di SDN 2 Dongko siswa masih mengalami kesulitan dalam membaca materi Aksara Jawa menggunakan pasangan. Dari 10 siswa yang ada 
dalam kelas tersebut, hanya 4 orang siswa yang bisa membaca Aksara Jawa, sedangkan 6 siswa lainnya masih bingung dan belum hafal membaca Aksara Jawa dengan pasangan. Sedangkan guru menjelaskan dengan cara ceramah dan dan tanya jawab.

\section{b. State Standards Objectives (Menentukan Standard Dan Tujuan)}

Tahap yang dilakukan selanjutnya adalah menetapkan Standart dan tujuan pembelajaran secara spesifik. Adapun Standar Kompetensi dan Kompetensi Dasar Serta indikator yang akan dipelajari sebagai berikut.

Tabel 1 Standar Kompetensi dan Kompetensi Dasar

\begin{tabular}{|c|c|c|}
\hline & \\
\hline & Standar Kompetensi & Kompetensi Dasar \\
\hline 1. & $\begin{array}{l}\text { Membaca Memahami } \\
\text { wacana tulis sastra dan } \\
\text { nonsastra dalam kerangka } \\
\text { budaya Jawa. }\end{array}$ & 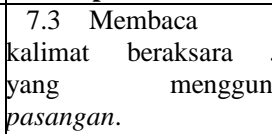 \\
\hline
\end{tabular}

c. Select Strategies, Materials, and Media (memilih strategi, bahan ajar dan media)

Rencana untuk penggunaan media dan teknologi, pertama-tama tentu saja menuntut pemilihan yang sistematis. Proses pemilihannya melibatkan beberapa langkah. Dalam proses pembelajaran dikelas nantinya peneliti akan menggunakan strategi tidak langsung karena pengembangan media ini difungsikan sebagai perantara siswa agar mudah memahami materi membaca aksara jawa menggunakan pasangan. Adapun bahan ajar yang digunakan peneliti yaitu menggunakan buku panduan pengunaan media yang didalamnya terdapat materi Aksara Jawa beserta pasangannya serta cara membaca Aksara Jawa menggunakan Pasangan. Adapun pemilihan media yang digunakan peneliti dalam melakukan penelitian ini yaitu menggunakan media PERDASAWA.
Media PERDASAWA ini merupakan jenis media visual grafis $3 \mathrm{D}$ yang diadopsi dari permainan tradisional dakon.

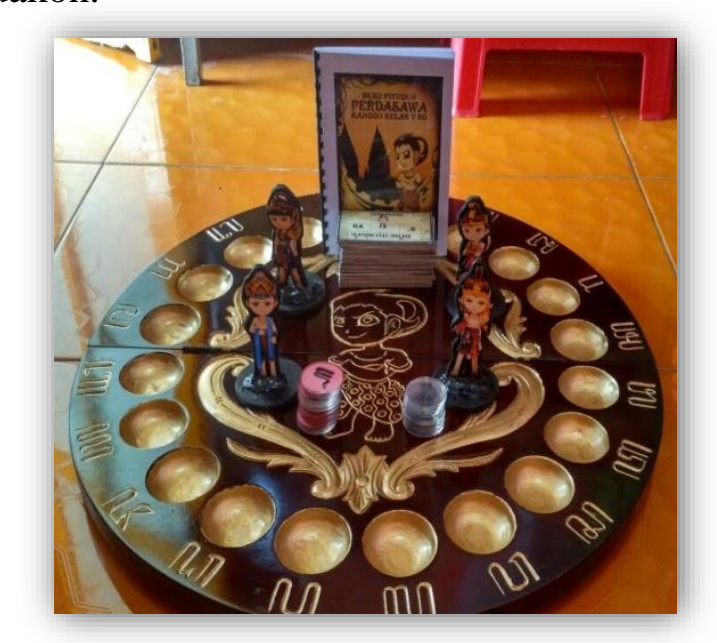

Gambar media perdasaawa

\section{d. Utilize Media And Materials ( Penggunaan Media Dan Bahan).}

Tahap Utilize Media And Materials merupakan tindak lanjut dari tahap pengembangan. Pada tahap ini media PERDASAWA yang dikembangkan akan diimplementasikan sekolah dasar. Penggunaan media perdasawa akan dilakukan di SDN 2 Dongko dan SDN 3 Ngerdani

\section{e. Require Learner Participation (Mengembangkan Peran Serta Siswa)}

Pada tahap mengembangkan peran serta siswa ini, peneliti memperoleh hasil dari melihat siswa menggunakan media perdasawa dan melihat angket respon siswa. Untuk hasil respon siswa melalui angket diperoleh hasil bahwa media perdasawa mendapatkan respon yang sangat positif sehingga siswa banyak yang berminat dan tertarik dengan adanya media perdasawa

\section{f. Evaluate And Revise (Menilai Dan Memperbaiki).}

Pada tahap evaluasi dan revisi ini peneliti melakukan penilaian terhadap siswa tentang sejauh mana siswa memahami materi dengan adanya 
media perdasawa. Untuk revisi sendiri dilakukan untuk memperbaiki kekurangan-kekurangan yang ada pada media perdasawa. Sehingga media perdasawa ini layak digunakan sebagai media pembelajaran..

\section{Hasil Penilaian Kelayakan Media Oleh Para Ahli}

Sebagai upaya untuk mengetahui kelayakan dan kelemahan produk media yang dikembangkan maka dilakukan penilaian (validasi) oleh ahli yang kompeten dibidangnya. Validasi dilakukan oleh ahli materi, ahli media, ahli pembelajaran.

\section{a. Validasi Ahli Materi tahap pertama}

Validasi yang dilakukan oleh ahli materi dilihat dari aspek isi (content) materi yang disajikan dalam media pembelajaran berupa buku penuntun/buku materi, kecik dan kartu soal. Adapun hasil yang diperoleh dari validasi media pembelajaran berdasarkan angket validator dapat diperoleh 61 skor dengan skor maksimal 70 dan menunjukkan presentase $87.14 \%$ sesudah revisi. Adapun rincian skor validator ahli materi pembelajaran sebagai berikut.

Tabel 2 Hasil Skor Validator Ahli Materi Sebelum Revisi

\begin{tabular}{|c|c|c|c|c|}
\hline No & Indikator & $\begin{array}{l}\text { Skor } \\
\text { Mak } \\
\text { sima } \\
\quad 1\end{array}$ & $\begin{array}{l}\text { Sko } \\
\mathbf{r} \\
\text { Hasi } \\
\mathbf{l}\end{array}$ & $\begin{array}{l}\text { Presen } \\
\text { tase } \\
\text { Skor } \\
\text { Hasil } \\
\end{array}$ \\
\hline 1. & $\begin{array}{l}\text { Kesesuaian dengan Standar } \\
\text { Kompetensi dan } \\
\text { Kompetensi Dasar }\end{array}$ & 5 & 4 & $80 \%$ \\
\hline 2. & $\begin{array}{l}\text { Kesesuaian dengan } \\
\text { kebudayaan Jawa }\end{array}$ & 5 & 4 & $80 \%$ \\
\hline 3. & Kebenaran cakupan materi & 20 & 17 & $85 \%$ \\
\hline 4. & $\begin{array}{l}\text { Kesesuaian penyampaian } \\
\text { materi }\end{array}$ & 5 & 4 & $80 \%$ \\
\hline 5. & $\begin{array}{ll}\begin{array}{l}\text { Kejelasan } \\
\text { penggunaan }\end{array} & \text { petunjuk } \\
\end{array}$ & 5 & 4 & $80 \%$ \\
\hline 6. & $\begin{array}{ll}\text { 8Kesesuaian } & \text { penyampaian } \\
\text { materi } & \text { menggunakan } \\
\text { media } & \\
\end{array}$ & 10 & 10 & $100 \%$ \\
\hline 7. & $\begin{array}{l}\text { Keterlibatan siswa dalam } \\
\text { pembelajaran }\end{array}$ & 10 & 9 & $90 \%$ \\
\hline 8. & $\begin{array}{l}\text { Keterciptaan sikap positif } \\
\text { siswa }\end{array}$ & 10 & 9 & $90 \%$ \\
\hline & jumlah & 70 & 61 & $\begin{array}{c}87.14 \\
\%\end{array}$ \\
\hline
\end{tabular}

Hasil penilaian ahli materi yang pertama memperoleh skor 61 dengan rata-rata 87.14. Berdasarkan pedoman konversi data kuantitatif ke kualitatif, media PERDASAWA Jawa masuk dalam kriteria layak digunakan

\section{b. Validasi Ahli Materi tahap kedua} Data-data yang diperoleh dari ahli materi pada tahap pertama berupa penilaian terhadap produk media pembelajaran yang dikembangkan kemudian dijadikan dasar penentuan kelayakan terhadap media. Komentar, kritik, dan saran yang diberikan ahli materi juga menjadi dasar dalam melakukan revisi sehingga produk media pembelajaran benar-benar layak untuk dikembangkan. Sehingga diharapkan ada peningkatan hasil yang diperoleh dari validasi pada tahap kedua ini.

Tabel 3 Hasil Skor Validator Ahli materi Sesudah Revisi

\begin{tabular}{clccc}
\hline No & \multicolumn{1}{c}{ Indikator } & $\begin{array}{c}\text { Skor } \\
\text { Mak } \\
\text { sima } \\
\text { I }\end{array}$ & $\begin{array}{c}\text { Sk } \\
\text { or } \\
\text { Ha } \\
\text { sil }\end{array}$ & $\begin{array}{c}\text { Prese } \\
\text { ntase } \\
\text { Skor } \\
\text { Hasil }\end{array}$ \\
\hline 1. & $\begin{array}{l}\text { Kesesuaian dengan } \\
\text { Standar Kompetensi dan } \\
\text { Kompetensi Dasar }\end{array}$ & 5 & 5 & $100 \%$ \\
\hline 2. & $\begin{array}{l}\text { Kesesuaian dengan } \\
\text { kebudayaan Jawa }\end{array}$ & 5 & 5 & $100 \%$ \\
\hline 3. & $\begin{array}{l}\text { Kebenaran cakupan } \\
\text { materi }\end{array}$ & 20 & 19 & $95 \%$ \\
\hline 4. & $\begin{array}{l}\text { Kesesuaian penyampaian } \\
\text { materi }\end{array}$ & 5 & 5 & $100 \%$ \\
\hline 5. & $\begin{array}{l}\text { Kejelasan petunjuk } \\
\text { penggunaan }\end{array}$ & 5 & 5 & $100 \%$ \\
\hline 6. & $\begin{array}{l}\text { Kesesuaian penyampaian } \\
\text { materi menggunakan } \\
\text { media }\end{array}$ & 10 & 10 & $100 \%$ \\
\hline K. & $\begin{array}{l}\text { Keterlibatan siswa dalam } \\
\text { pembelajaran }\end{array}$ & 10 & 8 & $80 \%$ \\
\hline 8. & $\begin{array}{l}\text { Keterciptaan } \\
\text { positif siswa }\end{array}$ & \multicolumn{1}{c}{ jumlah } \\
\hline
\end{tabular}

Hasil penilaian ahli materi pada tahap kedua memperoleh jumlah skor 67 dengan rata-rata 95.71. Berdasarkan pedoman konversi data kuantitatif ke kualitatif, maka produk media pembelajaran yang dikembangkan termasuk dalam kategori "Sangat Layak". Bila dibandingkan dengan hasil yang diperoleh pada tahap sebelumnya, 
tampak peningkatan skor yang cukup signifikan dari 61 ke 67 dengan rata-rata $87.14 \%$ menjadi $95.71 \%$.

\section{c. Validasi Ahli media tahap pertama}

Selain penilaian oleh ahli materi, media PERDASAWA juga dinilai oleh ahli media. Penilaian media dinilai oleh ahli media Ibu Arina Restian, M.Pd dosen dari jurusan PGSD. Penilaian pertama oleh ahli media dilakukan pada tanggal 12 januari 2018 di kantor Jurusan PGSD. Berikut hasil penilaian pertama oleh ahli media.

\section{Tabel 4 Hasil Skor Validator Ahli Media Sebelum Revisi}

\begin{tabular}{|c|c|c|c|c|}
\hline No & Indikator & $\begin{array}{c}\text { Skor } \\
\text { Mak } \\
\text { sima } \\
1\end{array}$ & $\begin{array}{c}\text { Sk } \\
\text { or } \\
\text { Ha } \\
\text { sil }\end{array}$ & $\begin{array}{c}\text { Pres } \\
\text { enta } \\
\text { se } \\
\text { Skor } \\
\text { Hasi } \\
\text { l }\end{array}$ \\
\hline 1. & $\begin{array}{l}\text { Kreativitas pembuatan } \\
\text { media }\end{array}$ & 10 & 10 & $\begin{array}{c}100 \\
\%\end{array}$ \\
\hline 2. & $\begin{array}{l}\text { Kemenarikan media } \\
\text { pembelajaran }\end{array}$ & 5 & 5 & $\begin{array}{c}100 \\
\%\end{array}$ \\
\hline 3. & Komposisi warna & 10 & 9 & $90 \%$ \\
\hline 4. & $\begin{array}{l}\text { Kekontrasan warna } \\
\text { background dengan } \\
\text { tulisan }\end{array}$ & 10 & 7 & $70 \%$ \\
\hline 5. & $\begin{array}{l}\text { Kesesuaian ukuran filed } \\
\text { dan kartu aksara }\end{array}$ & 5 & 5 & $\begin{array}{c}100 \\
\%\end{array}$ \\
\hline 6. & $\begin{array}{l}\text { Ketepatan ukuran tulisan } \\
\text { pada kartu aksara }\end{array}$ & 10 & 10 & $\begin{array}{c}100 \\
\%\end{array}$ \\
\hline 7. & $\begin{array}{l}\text { Kepraktisan dalam } \\
\text { penyimpanan }\end{array}$ & 5 & 5 & $\begin{array}{c}100 \\
\%\end{array}$ \\
\hline 8. & $\begin{array}{l}\text { Kemudahan penggunaan } \\
\text { media }\end{array}$ & 5 & 5 & $\begin{array}{c}100 \\
\%\end{array}$ \\
\hline 9. & $\begin{array}{l}\text { Kejelasan petunjuk } \\
\text { penggunaan }\end{array}$ & 10 & 8 & $80 \%$ \\
\hline 10. & $\begin{array}{l}\text { Kesesuaian media } \\
\text { dengan tingkat } \\
\text { perkembangan siswa }\end{array}$ & 5 & 5 & $\begin{array}{c}100 \\
\%\end{array}$ \\
\hline 11. & $\begin{array}{l}\text { Kesesuaian media } \\
\text { dengan tujuan } \\
\text { pembelajaran }\end{array}$ & 5 & 5 & $\begin{array}{c}100 \\
\%\end{array}$ \\
\hline 12. & $\begin{array}{l}\text { Keterlibatan siswa dalam } \\
\text { penggunaan media }\end{array}$ & 5 & 5 & $\begin{array}{c}100 \\
\%\end{array}$ \\
\hline 13. & $\begin{array}{l}\text { Ketepatan bahasa tulis } \\
\text { pada buku materi }\end{array}$ & 5 & 3 & $60 \%$ \\
\hline & jumlah & 90 & 82 & $\begin{array}{c}91.1 \\
\%\end{array}$ \\
\hline
\end{tabular}

(Sumber : Olahan Data Peneliti, 2018)

Hasil penilaian ahli media yang pertama memperoleh skor 81 dengan rata-rata $90 \%$. Berdasarkan pedoman konversi data kuantitatif ke kualitatif, media perdasawa masuk dalam kriteria sangat layak digunakan d. Validasi Ahli media tahap kedua

Berikut hasil penilaian oleh ahli media yang kedua.

Tabel 5 Hasil Skor Validator Ahli Media Sesudah Revisi

\begin{tabular}{|c|c|c|c|c|}
\hline No & Indikator & $\begin{array}{c}\text { Skor } \\
\text { Mak } \\
\text { sima } \\
\text { l }\end{array}$ & $\begin{array}{c}\text { Sk } \\
\text { or } \\
\text { Ha } \\
\text { sil }\end{array}$ & $\begin{array}{c}\text { Pres } \\
\text { enta } \\
\text { se } \\
\text { Skor } \\
\text { Hasi } \\
\text { l }\end{array}$ \\
\hline 1. & $\begin{array}{l}\text { Kreativitas pembuatan } \\
\text { media }\end{array}$ & 10 & 10 & $\begin{array}{c}100 \\
\%\end{array}$ \\
\hline 2. & $\begin{array}{l}\text { Kemenarikan media } \\
\text { pembelajaran }\end{array}$ & 5 & 5 & $\begin{array}{c}100 \\
\%\end{array}$ \\
\hline 3. & Komposisi warna & 10 & 10 & $\begin{array}{c}100 \\
\%\end{array}$ \\
\hline 4. & $\begin{array}{lr}\text { Kekontrasan } & \text { warna } \\
\text { background } & \text { dengan } \\
\text { tulisan } & \\
\end{array}$ & 10 & 10 & $\begin{array}{c}100 \\
\%\end{array}$ \\
\hline 5. & $\begin{array}{l}\text { Kesesuaian ukuran filed } \\
\text { dan kartu aksara }\end{array}$ & 5 & 5 & $\begin{array}{c}100 \\
\%\end{array}$ \\
\hline 6. & 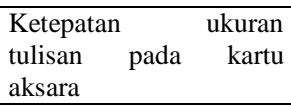 & 10 & 10 & $\begin{array}{c}100 \\
\%\end{array}$ \\
\hline 7. & $\begin{array}{ll}\text { Kepraktisan } & \text { dalam } \\
\text { penyimpanan } & \\
\end{array}$ & 5 & 5 & $\begin{array}{c}100 \\
\% \\
\end{array}$ \\
\hline 8. & $\begin{array}{l}\text { Kemudahan } \\
\text { penggunaan media }\end{array}$ & 5 & 5 & $\begin{array}{c}100 \\
\%\end{array}$ \\
\hline 9. & $\begin{array}{l}\text { Kejelasan petunjuk } \\
\text { penggunaan }\end{array}$ & 10 & 10 & $\begin{array}{c}100 \\
\%\end{array}$ \\
\hline 10. & $\begin{array}{l}\text { Kesesuaian media } \\
\text { dengan } \\
\text { perkembangan siswa }\end{array}$ & 5 & 5 & $\begin{array}{c}100 \\
\%\end{array}$ \\
\hline 11. & $\begin{array}{ll}\text { Kesesuaianp } & \text { media } \\
\text { dengan } & \text { tujuan } \\
\text { pembelajaran } & \end{array}$ & 5 & 5 & $\begin{array}{c}100 \\
\%\end{array}$ \\
\hline 12. & 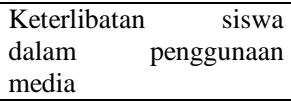 & 5 & 5 & $\begin{array}{c}100 \\
\%\end{array}$ \\
\hline 13. & $\begin{array}{l}\text { Ketepatan bahasa tulis } \\
\text { pada buku materi }\end{array}$ & 5 & 5 & $\begin{array}{c}100 \\
\%\end{array}$ \\
\hline \multicolumn{5}{|r|}{$\begin{array}{c}100 \\
\%\end{array}$} \\
\hline
\end{tabular}

Hasil penilaian ahli media yang pertama memperoleh skor 82 dengan rata-rata 91.1\%. Berdasarkan pedoman konversi data kuantitatif ke kualitatif, media perdasawa masuk dalam kriteria sangat layak digunakan. Bila dibandingkan dengan hasil yang diperoleh pada tahap sebelumnya, tampak peningkatan skor yang cukup signifikan dari 82 ke 90 dengan rata-rata $90 \%$ menjadi $100 \%$

\section{a. Validasi ahli Pembelajaran Pertama}

Validasi ahli pembelajaran kelas V SD dilaksanakan oleh guru pembelajaran 
kelas V. validasi dari ahli pembelajarab menilai dari segi media dan materu dalam media perdasawa. Adapun hasil yang diperoleh dari validasi media pembelajaran berdasarkan angket validator dapat diperoleh 102 skor dengan skor maksimal 130 dan menunjukkan presentase $78.46 \%$ sebelum revisi.

\section{a. Validasi Ahli Pembelajaran Tahap Kedua}

Sesudah melakukan validasi tahap pertama, dilakukan penilaian lagi untuk yang kedua kalinya. Adapun hasil yang diperoleh dari validasi media pembelajaran berdasarkan angket validator dapat diperoleh 121 skor dengan skor maksimal 130 dan menunjukkan presentase $93 \%$ sesudah revisi. Angka yang diperoleh melalai angket validasi ahli pembelajaran ini mengalami peningkatan yang cukup signifikan..

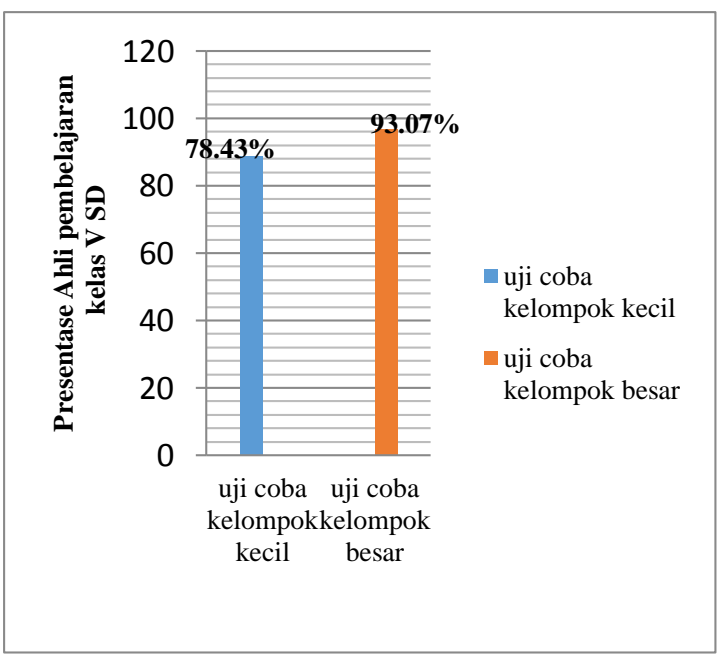

Gambar 2 Sumber: Peneliti - Grafik Batang Validasi Ahli

Pembelaran Kelas V SD Sebelum dan Sesudah Revisi

\section{Hasil Keterterapan Media Perdasawa}

Dalam mengetahui keterterapan media perdasawa ini maka hal yang dilakukan adalah melakukan Uji coba media.
Memerlukan partisipasi siswa dalam melakukan uji coba media. Sehingga peneliti melakukan uji coba media pad sekolah imbas yaitu SDN 2 Dongko dengan jumlah sampel 8 siswa dan uji kelompok besar di sekolah inti yaitpu SDN 3 Ngerdani dengan jumlah sampel 16 siswa. berikut ini tabel uji coba media:

\begin{tabular}{|c|c|c|c|}
\hline No & Uji Coba & Instasi & Sampel \\
\hline 1. & $\begin{array}{c}\text { Kelompok } \\
\text { Kecil }\end{array}$ & $\begin{array}{c}\text { SDN } 2 \\
\text { Dongko }\end{array}$ & 8 Siswa \\
\hline 2. & $\begin{array}{c}\text { Kelompok } \\
\text { Besar }\end{array}$ & $\begin{array}{c}\text { SDN } 3 \\
\text { Ngerdani }\end{array}$ & 16 Siswa \\
\hline
\end{tabular}

\section{a. Hasil Uji Coba Kelompok Kecil}

Ujicoba produk ini dilakukan pada kelompok kecil dan dilaksanakan pada hari Rabu, 07 januari 2018 dengan jumlah 8 .

Hasil respon siswa terhadap media dalam uji coba kelompok kecil diperoleh data secara rinci dan diketahui bahwa media yang dikembangkan mendapat respon positif sebagaimana ditunjukkan dari prosentase skor positif (Ya) yakni $88.75 \%$. Jika dikonversikan kedalam skala Guttman termasuk dalam kategori baik sekali.

\section{b. Hasil Uji Coba Kelompok Besar}

Ujicoba pemakaian ini dilakukan pada kelompok besar dan dilaksanakan pada hari Jumat, 9 januari 2018 dengan jumlah 16 dengan tingkat kemampuan yang berbeda. Ujicoba kelompok besar dilakukan sebagai masukan bagi peneliti sebelum media digunakan secara luas. Hasil respon siswa terhadap media dalam kelompok besar diperoleh data secara rinci yaitu jumlah skor respon positif (YA) yang diperoleh dari angket siswa mengenai responnya sesudah menggunakan media.

Kriteria penilaian respon siswa ujicoba kelompok besar jika 
dikonversikan ke dalam skala Likert menunjukkan menunjukkan presentase $96.87 \%$ sehingga proses pembelajaran menggunakan media PERDASAWA pada mata bahasa jawa dinyatakan mendapat respon positif dari siswa dan sangat layak atau sangat baik.

\section{PEMBAHASAN}

\section{Pengembangan Media}

PERDASAWA dengan model

ASSURE

a. Analyze Learner Characteristics (analisis karakter siswa)

Pada tahap ini analisis karakter siswa dilakukan di SDN 2 Dongko dan SDN 3 Ngerdani. Analisis ini digunakan untuk mengetahui kondisi nyata dilapangan, mengetahui kebutuhan yang harus dipenuhi di sekolah serta mengetahui karakteristik siswa kelas V Sekolah Dasar. Berdasarkan hasil analisis yang dilakukan di SDN 2 Dongko dan SDN 3 Ngerdani didapatkan hasil bahwa kedua sekolah tersebut memiliki kebutuhan yang sama yaitu pada media pembelajaran yang digunakan. Media pembelajaran yang digunakan bersifat tidak tahan lama sehingga media tidak dapat digunakan pada pembelajaran selanjutnya.

Jika disesuaikan dengan karakter siswa kelas V maka mereka berada pada tahap operasional konkrit dengan ciri masih suka bermain dan mampu berfikir konkrit. Maka media yang dikembangkan boleh diadopsi dari permainan yang mampu menarik perhatian siswa. Hal ini sependapat dengan apa yang dikatakan oleh (Hariyanto (2008:61) bahwa Cara lain agar siswa senang dalam belajar yaitu dengan memasukan permainan dalam proses pembelajaran. Berdasarkan analisis kebutuhan yang ada di sekolah, peneliti mengembangkan media pembelajaran yang bersifat tahan lama dan menarik untuk digunakan. Dibutuktikan dengan pendapat Arsyad (2010:75) bahwa salah satu kriteria media yang baik adalah media yang bersifat tahan lama. Media perdasawa ini dapat memberikan dampak yang positif kepada siswa. Dari segi kognitif dapat meningkatkan intelegensi siswa. Hal ini didukung dengan pendapat Menurut Yusuf (2006:24), menyatakan bahwa siswa sekolah dasar sering disebut dengan masa intelektual, sehingga adanya media pembelajaran dapat meningkatkan intelegensinya

\section{b. State Standards And Objectives (Menentukan \\ Standard Dan Tujuan)}

Pengembangan media perdasawa ini didasarkan pada SK dan KD Pembelajaran bahasa jawa kurikulum KTSP. Sehingga kejelasan dari landasan pengembangan media itu jelas dan dapat dipertanggungjawabkan. Sehingga media perdasawa ini dapat dijadikan sebagai perantara pengantar materi kepada siswa dengan baik. Hal dibuktikan dengan pendapat Sadiman (2010:6) media pembelajaran dijadikan sebagai perantara pengantar pesan. Hal ini juga berarti media sebagai alat bantu yang digunakan guru untuk menyampaikan materi kepada siswa agar siswa mudah memahami apa yang dijelaskan (Meylinda, 2015:68).

\section{c. Select Strategies, Materials, And Media (Memilih Strategi, Bahan Ajar Dan Media}

Pada tahap ketiga ini difokuskan pada pemilihan dan pengembangan media perdasawa saja. Untuk mengembangkan media yang baik maka kualitas media harus diperhatikan. Sehingga untuk mengembangkan media yang baik maka perlu memperhatikan beberapa kriteria tersebut baik kepraktisannya, 
kesesuaian dengan materi dan tujuan, bentuknya dll. Hal ini didukung dengan pendapat Arsyad (2010:75) bahwa kriteria media yang baik harus sesuai dengan tujuan pembelajaran, praktis, luwes, dan bertahan, berkualitas baik ukurannya sesuai dengan lingkungan.

\section{d. Utilize Media And Materials (Penggunaan Media Dan Bahan)}

Penggunaan media perdasawa ini akan mempermudah siswa dalam mempelajari materi membaca aksara jawa menggunakan pasangan. Hal itu dikarenakan telah ada penyisipan materi didalam media. Sehingga dengan adanya media ini akan membantu siswa memahami materi, memperluas pengetahuan dan cakrawala. Hal ini didukung dengan pendapat Arsyad (2010:25-27) manfaat dari penggunaan media pembelajaran adalah sebagai berikut: (1) dapat memperluas cakrawala materi, (2) memperoleh pengalaman yang beragam, (3) membantu keterbatasan indera, (4) dapat merangsang siswa intuk berfikir kritis, (5) meningkatkan efesiensi proses pembelajaran

\section{e. Require Learner Participation (Mengembangkan Peran Serta Siswa)}

Peran serta siswa disini untuk mengetahui seberapa besar media ini dapat menarik perhatian siswa dan mendapatkan respon positif dari siswa. Dalam penerapannya media perdasawa ini memiliki fungsi menarik perhatian siswa dan membuat siswa tidak bosan dalam pembelajaran. Hal ini dibuktikan dengan pernyataan Levie \& Lentz (dalam Arsyad, 2010: 50) media pembelajaran mempunyai empat fungsi salah satunya yaitu fungsi atensi yaitu penarik perhatian siswa. Didukung dengan pernyataan Sutikno (2013:50) fungsi media adalah untuk menghilangkan kebosanan siswa dalam belajar dan meningkatkan motivasi siswa.

\section{f. Evaluate And Revise (Menilai Dan Memperbaiki).}

Menilai dan memperbaiki ini bertujuan untuk menciptakan media perdasawa yang sesuai dengan tujuan pembelajaran dan karakteriktik siswa.

\section{Kelayakan Media Oleh Para Ahli}

Kelayakan media perdasawa diperoleh dari hasil angket validasi yang terdiri dari ahli materi, ahli media dan ahli pembelajaran. Tujuan digunakannya angket adalah untuk mengetahui penilaian responden (ahli materi, ahli media, ahli pembelajaran dan siswa) terhadap media yang dikembangkan. Responden diminta untuk mengisi lembar angket dan memberikan masukan berupa komentar, kritik dan saran sebagai bahan pertimbangan untuk melakukan revisi dan perbaikan media yang dikembangkan. Hal ini sesuai dengan pendapat (Sugiyono, 2012:199) bahwa dengan angket dapat mengetahui bentuk penilaian dan respon terhadap media yang dikembangkan. Sesuai dengan hasil yang telah diperoleh bahwa media perdasawa yang peneliti kembangkan itu layak digunakan sebagi media pembelajaran, dengan hasil validasi dari ahli materi $95.71 \%$, ahli media $100 \%$, ahli pembelajaran $93.07 \%$. jika konversikan ke skala likert dari (Arikunto, 2010:35) maka media perdasawa dikatakan layak digunakan.

\section{Keterterapan Media Perdasawa}

Keterterapan media perdasawa ini diperoleh dari hasil ujiciba media. Media perdasawa ini di uji cobakan pada 2 sekolah dasar dengan menggunakan kelompok kecil dan 
kelompok besar dengan sampel penelitian yang berbeda jumlahnya. Dari hasil yang telah dilakukan uji coba media dari kelompok kcil mendapatkan respon yang positif dari siswa sebesar $88.75 \%$ dan kelompok besar mendapatkan respon $96.87 \%$. hal inilah menjadikan bahwa media perdasawa sangat menarik dan mendapatkan respon yang sangat positif dari siswa yang sekaligus menguji keterterapan media. Hal tersebut sesuai dengan pendapat Sutikno (2013:50) fungsi media adalah untuk menarik perhatian siswa dalam belajar.

\section{SIMPULAN}

1. Media perdasawa ini layak digunakan. Model pengembangannya menggunakan model ASSURE. Model ini membantu guru dalam memilih atau mengembangkan media didalam kelas, supaya membantu proses pembelajaran. model pengembangan ASSURE mulai dengan tahap analyze learner characteristics (analisis karakter siswa), state standards and objectives (menentukan standard dan tujuan), select strategies, materials, and media (memilih strategi, bahan ajar dan media), utilize media and materials (penggunaan media dan bahan), require learner participation (mengembangkan peran serta siswa), evaluate and revise (menilai dan memperbaiki).

2. Hasil dari pengembangan media perdasawa ini termasuk kategori sangat baik dan layak digunakan. Hal tersebut diperoleh dari hasil prosentasi validasi yang terdiri dari validasi ahli materi $95.71 \%$, ahli media $100 \%$, ahli pembelajaran 93.07\% . pada tahap uji coba media juga mendapatkan respon yang sangat positif dari siswa.

3. Untuk mengetahui keterterapan media maka media diuji cobakan pada siswa. Dalam uji coba skala kecil mendapatkan respon $88.75 \%$ dan kelompok besar mendapatkan respon $96.87 \%$. hal inilah menjadikan bahwa media perdasawa sangat menarik dan mendapatkan respon yang sangat positif dari siswa yang sekaligus menguji keterterapan media dalam proses pembelajaran. Sehingga dapat peneliti simpulkan bahwa media PERDASAWA ini layak digunakan sebagai media pembelajaran untuk mata pelajaran bahasa jawa materi membaca aksara jawa menggunakan pasangan untuk kelas V Sekolah Dasar.

\section{DAFTAR PUSTAKA}

Aisyah, Fad. 2011. Kumpulan Permainan Anak Tradisonal Indonesia. Jakarta: Penebar Swadaya

Arsyad, Azhar. 2010. Media Pembelajaran. Jakarta : PT. Raja Grafindo Persada.

Arsyad, Azhar. 2012. Media Pembelajaran. Jakarta : PT. Raja Grafindo Persada.

Depdiknas. 2007. Kamus Besar Bahasa Indonesia. Jakarta: Balai Pustaka.

Mandala, Warta. 2013. DAKON: Filosofi dan Nilai Pendidikan Permainan Dakon. Diakses melalui http://www.wartamadani.com/20 13/02 /dakon-filosofi-dan-nilaipendidikan.html pada tanggal 7 Desember 2017 
Maisaroh, Novi. 2011. Pengembangan Media Pembelajaran Sains Berorientasi Cooperative Learning Pada Siswa SD Menggunakan Bahan Daur Ulang. Yogyakarta: UNY

Meylinda, F. 2015. Pengembangan Media Pembelajaran Keterampilan Berbicara dengan Program Adobe Flash Untuk Siswa Kelas $V$ SD. Jurnal Review Pendidikan Dasar. Vol 1. Nomor 1 September 2015. NISN: 2460-8475: 68

Mulyana (ed). 2008. Pembelajaran Bahasa dan Sastra Daerah dalam Kerangka Budaya. Yogyakarta: Tiara Wacana.

Mulyana. 2008. Bahasa dan Sastra Daerah dalam Kerangka Budaya. Yogyakarta: Tiara Wacana.

Pranowo, G. 2013. Pengembangan Media Flash Cards Untuk Meningkatkan Kemampuan Membaca Aksara Jawa Bagi Siswa SD. JP2SD: 3

Prihatin, K. 2015. Pengembangan Multimedia Interaktif Aksara Jawa untuk Pembelajaran Bahasa Jawa Siswa Kelas V SD Negeri Sabdodadi Keyongan Bantul. jurnal pendidikan, 16.

A.M. 2007. Interaksi dan Motivasi Belajar Mengajar. Jakarta: Raja Grafindo Persada.

Sanjaya, Wina. 2008 Perencanaan dan Desain Sistem Pembelajaran. Bandung:Kencana Prenada Media Group.
Smaldino, S.E., dkk. 2011. Instructional Technology and Media for Learning. Upper Saddle River: Pearson Educatiom, Inc.

Standarisi. 2013. Kurikulum 2013 Mata Pelajaran Muatan Lokal Bahasa Jawa SD/SDLB/MI. Jurnal Pendidikan, 15

Tim Penyusun Undang-Undang Sisdiknas. (2006). Undangundang Sistem Pendidikan Nasional. Yogyakarta: Pustaka Pelajar

Yusuf, Syamsu 2006. Psikologi Perkembangan Anak dan Remaja. Bandung: Remaja Rosdakarya 